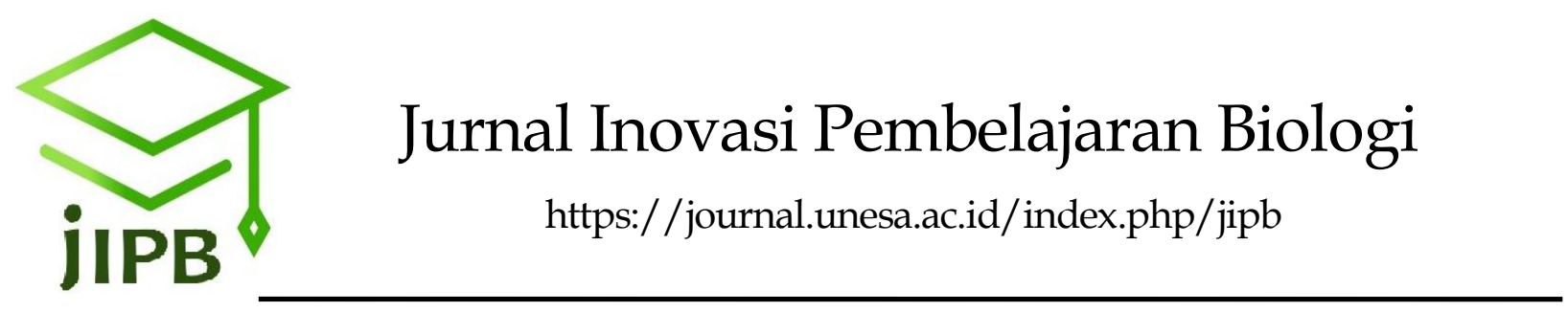

\title{
Implementation of Blended Learning using Schoology On the Topic of Invertebrate to Improve Student Learning Outcomes
}

\author{
Fikky Dian Roqobih*, Reni Ambarwati \\ Jurusan Biologi, FMIPA, Universitas Negeri Surabaya \\ Jl. Ketintang Surabaya 60231 \\ E-mail: fikky911@gmail.com
}

\section{HISTORY OF ARTICLE:}

Received: 3 Desember 2020

Accepted: 25 Januari 2020

Published: 11 Maret 2020

Keywords: Blended learning, schoology, invertebrate

\begin{abstract}
Invertebrate is a very wide topic, that includes approximately eight phyla. Problem in teaching this topic is the limitation in time to achieve many learning indicators. The alternative effort to overcome this problem is by implementing the blended learning. Blended learning is a kind of learning that combines face-toface learning in the classroom and online learning that can be conducted everywhere. This study aimed to evaluate the learning process of blended learning using Schoology, student responses and students learning outcomes of invertebrate material through blended learning using Schoology. This research was conducted by involving 33 students of Grade X by using one group pre-test and post-test design. Data obtained were learning process based on lesson plan and student activities, student responses as well as students learning outcomes. Instruments used were observation sheets, responses questionnaires, as well as pretest and posttest sheets. The data of learning process and student activities were analyzed descriptivequantitatively. Data of learning outcomes were analyzed based on learning mastery and gain score. The results of this study indicated that learning process of both face-to-face learning and online learning were very successful, students also gave very good responses to the implementation of blended learning. In addition, it's proven that the implementation of blended learning can improve the student learning outcomes significantly.
\end{abstract}

\section{INTRODUCTION}

Kingdom Animalia is one of the chapters in Biology subject for Grade X of senior high school that includes classification of invertebrates and vertebrates. The time allocation for these materials is eight lesson hours. It means that time allocation for invertebrate material is four lesson hours to discuss about eight phyla that include general and specific characteristics of each phylum as the basis for the classification and role of these animals in 
life. Therefore, some problems often occur during learning this chapter because of limited time for classroom learning or face-to-face learning.

One strategy that can be applied to help students in learning and understanding overall invertebrate material is blended learning. According to Austria et al. (2015), blended learning is part of multimedia that utilizes electronic learning (e-learning), educational technology and learning management system. Blended learning combines online learning with conventional face-to-face learning components as an alternative model of learning. Besides, Sicat (2015) stated that blended learning is a student learning system that can be done anytime through online material to solve various learning problems related to time, place, and learning stages. In addition, Chen and Jones (2007) argued that blended learning could help student to gain the concept understanding because they can access more resources from the web and some articles illustrating that concept.

In order to deliver the online learning as a part of blended learning, a tool is needed. One of these tools is Schoology. Aminoto et al. (2014) mentioned that Schoology combines some features of a learning management system (LMS) and some social networking features. Schoology also offers learning that same with classroom learning for free and user friendly because it looks like social media Facebook (Putri et al., 2014). The usage of Schoology can be integrated with face-to-face learning for example with practicum. Learning with Schoology had been applied and could enhance the students' average scores up to $47 \%$ (Putri et al., 2014). In addition, it had also been applied to the energy topic and could increase $38.84 \%$ of student's concept mastery (Aminoto \& Pathoni, 2014). Recent research also revealed that students gave positive response to Schoology-based blended learning media for Basic Physics Course (Suana et al., 2017). The Appearance of Schoology can be seen in Figure 1.

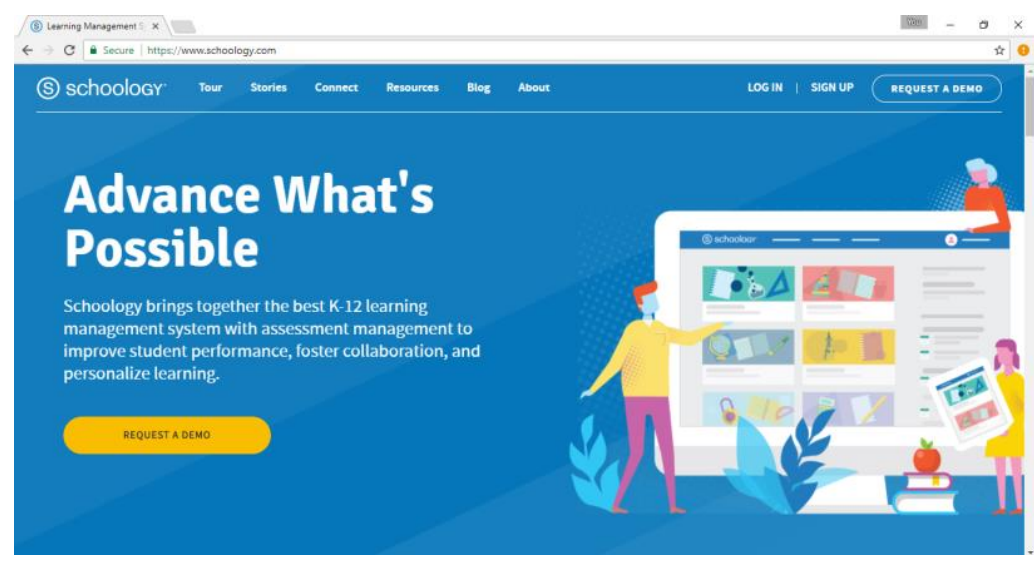

Figure 1. The Appearance of Schoology.

For the learning of invertebrates, blended learning can combine online learning using Schoology with face-to-face learning in the classroom for hands on activities, for example by doing practicum. Practicum is face-to-face learning that emphasizes psychomotor, cognitive, and affective to use equipment in the laboratory or experiment field. Practicum can improve the ability of student constructivist. As a result, the students can build a concept in their own mind. Practicum can be carried out by experiment as well as observation (Litasari, et al., 2014).

The implementation of blended learning using Schoology and observation activities in the classroom learning is potential to improve the learning outcomes. This study aimed to evaluate learning process, student responses and student learning outcomes toward blended learning using Schoology for invertebrate topic. 


\section{METHODS}

This was pre-experimental research that was conducted based on one group pre-test post-test design. The research was carried out in one of senior high school in Surabaya on the second semester of academic year of 2016/2017, involving 33 students.

The treatment applied in this research was the implementation on blended learning consisted of face-to-face or classroom learning and online learning. The classroom learning was delivered by learning the invertebrates through observation-based practicum. During this face-to-face learning, students learn to identify and classify the invertebrates into each phylum based on their morphological characters. Through observation, students construct the concept of classification of invertebrates. Meanwhile, the online learning was delivered by using Schoology. The teacher created invertebrate course on Schoology and invited the students to join this course. This online learning provided multimedia such us photos, articles, and videos to learn about the general characters of invertebrates and the role of invertebrates as well. The course on Schoology also provided space for discussion, evaluation, and task.

The research instruments were consisted of treatment instruments and data collection instruments. The treatment instruments were consisted of syllabus, lesson plan, as well as student worksheet; meanwhile instruments for data collection were observation sheet of face-to-face and online learning process, student activity observation sheet, response questionnaire sheet, as well as pre-test and post-test. Prior to the implementation, all of instruments were validated by experts. The experts' validation revealed that the instruments were valid and could be used in the learning. Observers based on the instruments observed the learning process and students' activities.

Data of learning process and the students' activities as well as the student responses were analysed descriptive-quantitatively. The learning outcomes were measured based on score of written test. The score were analysed based on gain score, individual mastery and mastery of learning indicators. Individual student was stated to be completed if their test score was more than 76. Mastery of learning indicators was determined by percentage of student concept mastery for each indicator.

\section{RESULTS AND DISCUSSION}

Effect of blended learning implementation using Schoology on topic of invertebrates for grade $X$ was analysed based on learning process, students' responses, and learning outcomes. Learning process assessed based on observations of lesson plan and student activities. Instrument used were observations sheet. All aspects of blended learning had be done well either in face-to-face meeting or online meeting. Face-to-face learning process in detail described in Table 1, while online learning process in detail described in Table 2.

Table 1. Learning Process of Face to Face Meeting

\begin{tabular}{lll}
\hline No. & Meeting & Percentage $(\mathbf{\%})$ \\
\hline 1. & I & 100 \\
\hline 2. & II & 100 \\
\hline 3. & II & 100 \\
\hline
\end{tabular}

Blended learning using Schoology on invertebrate topic could be carried out based on lesson plan. This was proven by observation result by three observers using learning process observation sheet. Blended learning that applied in this research consisted of three meetings 
of face-to-face learning and three meeting of online learning. As the statement of Sicat (2015), that blended learning is a combination of face-to-face learning and online learning.

In the second meeting of face-to-face learning, students were divided into groups that consist of five to six students to create more effective learning. This condition was also suitable with the statement of Haryanto (2001), which is strategy to create an effective learning in the classroom is forming small groups and arrange student seat. Face to face learning ran well with percentage of $100 \%$, which means all learning stages were carried out.

All of learning stages on first meeting of online learning were carried out. Meanwhile, percentage of second meeting in class was $90 \%$ because there was no students ask question to teacher and other student. Students also did not discuss with their friend about their difficulties when did quiz in the third meeting (Table 2). Interaction that occurs is among teacher and students because students did not know the right answer.

Table 2. Learning Process of Online Meeting

\begin{tabular}{ccc}
\hline No. & Meeting & Percentage (\%) \\
\hline 1. & I & 100 \\
\hline 2. & II & 90 \\
\hline 3. & II & 90 \\
\hline
\end{tabular}

Wang (2014) stated that the role of teachers was very important to overcome unmaximal discussion, by giving questions that could stimulate students to express their opinions. The types of questions that could be asked to students were about reasons, references, their different point of view, examples or illustrations that represented student's answers. It would improve student communication skills in the discussion. Cho and Tobias (2016) added that teachers at least upload an information or content both in the Group and discussion room one day related to the material or non-material to make students interact with others in the online media so that students would be active during the discussion. Farlane (2011) also stated that passive discussion often happened in online discussion because some reasons such as slow internet connection. Those who had strong connections could download or view contents faster and monopolize the discussion and it was little bit difficult to arrange the schedule since that online learning was conducted outside the school time.

Another statement proposed by Ermilyaz (2015) that online learning was used to prepare the next lesson so teacher can use face to face meeting to create a discussion among students. Thus, in an online meeting student are not required to conduct discussion with other students.

Learning process also observed based on student activity during blended learning using Schoology. Students' activities that observed were activities in face-to-face learning and online learning. Student activity in face-to-face learning was excellent with the percentage $97.3 \%$ (Table 3 ).

Table 3. Student Activity in Face-to-Face Learning

\begin{tabular}{clc}
\hline No. & Activities & Percentage (\%) \\
\hline 1. & Student read general instruction inside Student Worksheet & 75.8 \\
\hline 2. & Student read objectives inside Student Worksheet & 100 \\
\hline 3. & $\begin{array}{l}\text { Student read procedures, materials and equipment that } \\
\text { necessary before observation. }\end{array}$ & 100 \\
\hline 4. & Student did practical activity based on worksheet & 100 \\
\hline 5. & Student conducted observation in a group & 100 \\
\hline
\end{tabular}




\begin{tabular}{cllcc}
\hline No. & Activities & & Percentage (\%) \\
\hline 6. & $\begin{array}{l}\text { Student analyzed morphological characteristics of } \\
\text { invertebrate animals provided }\end{array}$ & 100 \\
\hline 7. & $\begin{array}{l}\text { Student classified invertebrate animals based on } \\
\text { morphological characteristics. }\end{array}$ & 100 \\
\hline 8. & $\begin{array}{l}\text { Student determined phylum of each group invertebrate } \\
\text { animals. }\end{array}$ & 100 \\
\hline 9. & $\begin{array}{l}\text { Student wrote simple report about one invertebrate } \\
\text { phylum. }\end{array}$ & 100 \\
\hline & Average & 97.3 \\
\hline
\end{tabular}

Those students' activities were classified into very good category. Students were trained to read objectives and procedures before conducted the observation. Then students analysed, grouped, and determined the invertebrate phyla of some animals based on their morphological characteristics. Next, they summarized into simple report about one phylum, which are Coelenterata, Annelids, Arthropods, and Echinoderm. Students' activities in online learning using Schoology also gained very good category that showed by average percentage $86.5 \%$ (Table 4 ).

Table 4. Student Activities in Online Learning

\begin{tabular}{cllc}
\hline No. & Activities & Percentage (\%) \\
\hline 1. & Student loged in their own Schoology account & 100 \\
\hline 2. & $\begin{array}{l}\text { Student commented information that are shared by } \\
\text { teacher in Group }\end{array}$ & 48.8 \\
\hline 3. & $\begin{array}{l}\text { Student commented learning content/source that are } \\
\text { uploaded in Schoology }\end{array}$ & 43 \\
\hline 4. & $\begin{array}{l}\text { Student participated in discussion within Schoology } \\
\text { account }\end{array}$ & 100 \\
\hline 5. & $\begin{array}{l}\text { Student did Task 1 about general characteristics of each } \\
\text { invertebrate phylum in Schoology }\end{array}$ & 100 \\
\hline 6. & $\begin{array}{l}\text { Student did Task 2 about roles of each invertebrate } \\
\text { phylum in Schoology }\end{array}$ & 100 \\
\hline 7. & $\begin{array}{l}\text { Student did Quiz 1 that already uploaded by teacher in } \\
\text { Schoology as a practice }\end{array}$ & 100 \\
\hline 8. & $\begin{array}{l}\text { Student did Quiz 2 that already uploaded by teacher in } \\
\text { Schoology as a practice. }\end{array}$ & 100 \\
\hline \multicolumn{1}{c}{ Average } \\
\hline
\end{tabular}

Student online learning activities were also categorized very well with the percentage of student activity of $86.5 \%$. The advantages of online learning using the Schoology application, which students can participate in discussions in the chat room, work on online tasks as learning resources such as Task 1 about the general characteristics of invertebrates or Task 2 about the role of invertebrates, and answer questions about invertebrate animals as an exercise to make student get deeper understanding of invertebrate. As stated by Eryilmaz (2015), that blended learning had various advantages such as flexibility in terms of location and time, sharing of online learning resources, interaction between students and teachers both inside class and outside of class with online learning. Students have more time to learn and understand more invertebrate concept. However, there are some online activities that were not maximal, which were just $48.8 \%$, namely student commented on information and $43 \%$ student commented the learning content uploaded on Schoology. This was because researchers did not give written instruction on Schoology page to do those activities. 
Instructions are given only at the beginning of the course, whereas according to Geng (2011) the provision of repetitive instruction is very necessary for students to remind them that students pass all the learning stages desired by the teacher. Geraci (2006) adds that instruction has a very important role as a means of reminding students in learning.

Students' responses were measured using student response questionnaire sheet. Student gave their opinion about the learning based on some criteria of face-to-face, online, and blended learning according to their experience. Most of students gave very good response to face-to-face, online, and blended learning. The details of the percentage were 93.8\% for face-to face learning, $91.7 \%$ for online learning, and $96.5 \%$ for the whole process of blended learning. Therefore, it could be stated that the students gave very good responses (Table 5).

Table 5. Student's Responses Toward the Implementation of Blended Learning Using Schoology

\begin{tabular}{|c|c|c|}
\hline No. & Criteria & Percentage (\%) \\
\hline \multicolumn{3}{|c|}{ Face-to-face learning } \\
\hline 1. & $\begin{array}{l}\text { Practicum learning atmosphere about invertebrate was interesting } \\
\text { and pleasing for student }\end{array}$ & 100 \\
\hline 2. & $\begin{array}{l}\text { Face-to-face learning by practicum made student easier to know } \\
\text { morphological characteristics of each invertebrate phylum. }\end{array}$ & 100 \\
\hline 3. & $\begin{array}{l}\text { Face-to-face learning by practicum made students easier to } \\
\text { classify invertebrate animal. }\end{array}$ & 87.5 \\
\hline 4. & $\begin{array}{l}\text { Face-to-face learning by practicum made students easier to } \\
\text { determine invertebrate phylum }\end{array}$ & 87.8 \\
\hline & Average & 93.8 \\
\hline \multicolumn{3}{|c|}{ Online learning } \\
\hline 1. & $\begin{array}{l}\text { Online learning atmosphere about invertebrate using Schoology } \\
\text { was a new experience for students }\end{array}$ & 100 \\
\hline 2. & $\begin{array}{l}\text { Online learning atmosphere about invertebrate using Schoology } \\
\text { was interesting and joyful for students }\end{array}$ & 96.9 \\
\hline 3. & $\begin{array}{l}\text { Schoology media could facilitate students to held discussion } \\
\text { outside lesson hour }\end{array}$ & 64.1 \\
\hline 4. & $\begin{array}{l}\text { Schoology media made students easier to learn about invertebrate } \\
\text { material outside lesson hour. }\end{array}$ & 100 \\
\hline & $\begin{array}{l}\text { Material in Schoology media supported student's lesson and } \\
\text { information about invertebrate }\end{array}$ & 100 \\
\hline 6. & $\begin{array}{l}\text { Through online learning using Schoology, students could } \\
\text { understand general characteristics and roles of invertebrates }\end{array}$ & 63,6 \\
\hline & $\begin{array}{l}\begin{array}{l}\text { Schoology could improve student's motivation to learn } \\
\text { independently }\end{array} \\
\end{array}$ & 100 \\
\hline 8. & $\begin{array}{l}\text { Schoology helped students to observe invertebrate parts, which } \\
\text { cannot be observed directly }\end{array}$ & 100 \\
\hline & $\begin{array}{l}\text { Schoology features supported student's learning process about } \\
\text { invertebrate material }\end{array}$ & 100 \\
\hline & Average & 97.1 \\
\hline \multicolumn{3}{|c|}{ Blended Learning } \\
\hline 1. & $\begin{array}{l}\text { Material content of invertebrate in Schoology was suitable when } \\
\text { combined with practicum. }\end{array}$ & 100 \\
\hline 2. & Blended learning using Scholoogy was a new thing for students & 100 \\
\hline 3. & $\begin{array}{l}\text { Learning atmosphere using blended learning was interesting and } \\
\text { pleasing students. }\end{array}$ & 97.1 \\
\hline 4. & Students felt more motivated when learn with blended learning & 100 \\
\hline
\end{tabular}


Roqobih \& Ambarwati, Implementation of Blended Learning...

\begin{tabular}{lllcc}
\hline No. & Criteria & & Percentage (\%) \\
\hline & using Schoology & & \\
\hline 5. & $\begin{array}{l}\text { Blended learning makes students easier to understand } \\
\text { invertebrate material }\end{array}$ & 100 \\
\hline 6. & $\begin{array}{l}\text { By using blended learning, students can access invertebrate } \\
\text { material anywhere and anytime }\end{array}$ & 78.7 \\
\hline 7. & $\begin{array}{l}\text { By using blended learning students can be easier to understand all } \\
\text { invertebrate phylum }\end{array}$ & 100 \\
\hline & Average & $\mathbf{9 6 . 5}$ \\
\hline
\end{tabular}

Students responded very well to those criteria's of blended learning, such as laboratory activities, which were interesting and facilitated the students to know the morphological characteristics of each invertebrate phyla, but there were a small number of students who were still difficult to classify and determine the phyla of an animal. This could be overcome by the addition of morphological characteristics in invertebrate animals observations, such as surface structure, posterior or anterior body shape, presence of cetae rigid hair, and more detail body shape likely flat or leafy or cylindrical and so on. This statement is in accordance with the opinion of Kilic (2016), which stated that teachers should specify the various morphological characteristics that might be observed to facilitate students looking for morphological similarity in order to classify invertebrate animals.

Students also gave very good response to some criteria of blended learning, such as Schoology made them easier to learn invertebrate material, media features that supported learning, helped to observe the parts that were not visible, appropriate content and made them easier to understand the material. Besides, according to students' blended learning using Schoology was a new thing so students felt more interested and motivated to study. Blended learning research which concluded by $\mathrm{Xu}$, et al., (2008) showed that student were agree that by using online application they became easier to understand the topic in textbook and student felt enjoy with those online learning.

Various advantages of Schoology compared to other online tools were the appearance of Schoology closely similar to social media Facebook, hence the students became easier to learn about the features, updated information which related to the material, could access either via personal computer or mobile phone since it is provided in application form that can be downloaded by the students for free, teacher could create questions that will be discussed together, the students can also see their presence and score. In addition, Students can give comments and take some innovative tests, quiz or resources that completed with picture, video, and other website links. Types of questions are also varied such as matching, true or false, short answer, and essay (Sicat, 2015).

On the other hand students assumed that Schoology could not be accessed anywhere and at any time because there were some content that must be accessed via computer and some students still difficult to understand general characteristics of invertebrates through the content in Schoology. According to Hsu et al., (2015), not all students can learn independently. Direct guidance from teacher is required to guide students in high level of cognitive task. Upitis and Brook (2014) stated that students still need teacher guidance even in self learning concept to monitor, provide feedback, and reinforcement of learning progress.

Result of research that conducted by Yapici and Akbayin (2012) on blended learning which combines the advantages of face to face learning and online learning in Nevzat Ayaz Anatolian High School for the material "Classification of Living Things and Biodiversity" obtained a positives response from students. They also added that with implementation of 
blended learning student could get effective learning by the combination of face to face learning and online learning via internet. Face-to-face learning could be carried out as well as online learning so both learning could be integrated into blended learning.

Based on the pre-test result, as much as $100 \%$ of students declared incomplete with mean score 31.2 (Table 6). This was caused by students did not have prior knowledge about invertebrate material so they still in the low level of material understanding. Besides, student also could not learn independently without any guidance and reinforcement from teacher.

After students get lesson through blended learning using Schoology in invertebrate material, student learning outcomes were measured using post-test. From this post-test result as much as $100 \%$ students declared to be completed with mean score 86.6. The improvements between both scores were calculated with gain score. Then the result was 0.8 then it was interpreted in the table-normalized category of gain score. Based on that table, student learning outcomes that analysed by N-Gain score involved in the "High" category (Table 6).

Table 6. N-Gain Score Student Learning Outcomes Based on Pre-test and Post-test

\begin{tabular}{|c|c|c|}
\hline N-Gain Score & Amount of Students & Percentage (\%) \\
\hline 0.7 & 18 & 54.5 \\
\hline 0.8 & 9 & 27.3 \\
\hline 0.9 & 6 & 18.2 \\
\hline Average & & \\
\hline Category & & \\
\hline
\end{tabular}

Classically a class declared as complete if $75 \%$ of students reached a score more than 76. Post-test result showed $100 \%$ students were complete so both classes declared $100 \%$ to be complete because no one get score below the standard. As statement of Garrison \& Kanukan (2004), blended learning can help students to improve their knowledge of invertebrate concept.

Implementation of blended learning using Schoology in invertebrate material could achieve thirteen indicators, which were four indicators taught in face-to-face meeting and nine indicators taught in online meeting. The average mastery of these indicators was $89.2 \%$. The mastery of each learning indicator was detailed in Table 7.

Table 7. Mastery of Learning Indicators

\begin{tabular}{llc}
\hline No. & Learning Indicator & Percentage (\%) \\
\hline \multicolumn{2}{l}{ Face to face learning } \\
\hline 1. & Analyzing morphological characteristics of invertebrates & 100 \\
\hline 2. & Classifying invertebrate animals into each phylum & 96.5 \\
\hline 3. & Determinining phylum of an animal & 97.1 \\
\hline 4. & Describing specific characteristic of Porifera & 100 \\
\hline \multicolumn{2}{c}{ Average } \\
\hline \multicolumn{2}{l}{ Online learning } & $\mathbf{9 8 . 4}$ \\
\hline 5. & Explaining water canal in Porifera & 92.4 \\
\hline 6. & Explaining Colenterata Reproduction & 72.4 \\
\hline 7. & Explaining Platyhelminthes Reproduction & 85.2 \\
\hline 8. & Explaining division of Invertebrate based on coelom. & 67.7 \\
\hline
\end{tabular}




\begin{tabular}{clc}
\hline No. & Learning Indicator & Percentage (\%) \\
\hline 9. & Explaining reproduction characteristics of Annelid & 75 \\
\hline 10. & Explaining mantle function of Molluscs & 100 \\
\hline 11. & Explaining body parts of Arthropods & 86.4 \\
\hline 12. & Explaining ambulacral system in Echinodermata & 87.3 \\
\hline 13. & Analyzing roles of invertebrate animal in daily life & 100 \\
\hline \multicolumn{2}{c}{ Average } & $\mathbf{8 5 . 1}$ \\
\hline & Total Average (\%) \\
\hline
\end{tabular}

Wai \& Seng (2015) stated that blended learning can improve student learning outcomes because students got a meaningful learning experience. Blended learning made students process a material or information easier because it used multimedia such as videos, pictures or exercises that could be accessed and done by students through Schoology. Bindu \& Tara (2016) also revealed that blended learning was effective and can improve student learning outcomes in Biology lesson because students were facilitated with various learning resources and media. This opinion was linked to student learning outcomes in this study. Highest student mastery was shown in several learning indicators, which were "Explain the mechanism of water channels in Porifera" and "Analyze the roles of invertebrates in daily life". Students were provided videos and website links that could be used as learning resources to achieve those indicators.

However, mastery of some online learning indicators was low, which were "explains the reproduction of Coelenterates, Annelid and the division of invertebrates based on the coelom caused by the material on those indicators required a sufficient understanding of the previous concept. The concepts that students needed to understand previously include the concept of anatomical structures of invertebrates. This knowledge was not obtained by students because it was not listed in the syllabus; hence the students need other books as a reference to learn that concept. In addition, conventional learning that usually used was teacher centered also caused low ability of students in constructing knowledge in their minds. According to Jaleel and Verghis (2015), students might have initial knowledge as a basis for building a concept of subsequent knowledge. This statement was supported by Sheperd \& Tello (2015) that a material presented by the teacher would be fully understood by the student if student had gained initial knowledge of related material.

The highest mastery of online indicators was "analyse positive and negative roles of invertebrate animals because resources for this indicator some news articles. Students were given links to articles; hence they could read and analysed the role of invertebrates. It could deepen student understanding about the role of invertebrates in the daily life. Bindu \& Tara (2016) stated that the usage of various resources available on the internet could help students to gain wider knowledge. Overall, the average indicators mastery of blended learning using Schoology was $93.8 \%$ (very good). According to research by Chen and Jones (2007), blended learning can improve student analytical, interpersonal and computer skills.

Therefore, blended learning using Schoology on invertebrate topic had been done very well. Student activity in this learning was also included in very well category. In addition, students also responded very well to this lesson. Blended learning using Schoology had been shown significantly improve student learning outcomes.

\section{CONCLUSION}

Based on the analysis and discussion, it could be concluded that blended learning using Schoology in invertebrate material based on of lesson plan and student activities could be classified in very good category. This learning also got very good response from students. 
Students stated that online learning using Schoology had many advantages, such as could be accessed both via mobile phone and downloaded for free, the display also user friendly because similar to Facebook, materials and exercises which uploaded are varies and interesting with picture, video and website links. Blended learning also can improve student learning outcome either individually or classically, and can achieve thirteen learning indicators with very good average.

\section{ACKNOWLEDGEMENT}

We are very grateful to Dr. Fida Rachmadiarti, M.Kes, Mrs. Ulfi Faizah, S.Pd., M.Si, and Prof. Dr. Endang Susantini, M.Pd. for their valuable comments for the improvement of this research.

\section{REFERENCES}

Aminoto, T., \& Pathoni, H. (2014). Penerapan Media E-learning Berbasis Schoology untuk Meningkatkan Aktivitas dan Hasil Belajar Materi Usaha dan Energi di Kelas XI SMA N 10 Kota Jambi. Jurnal Sainmatika, 8(1), 13-29.

Arikunto, S. (2010). Prosedur Penelitian Suatu Pendekatan Praktik. Jakarta: Rineka Cipta.

Austria, M. M., Dasig, D. D. and Valderama, A. M. (2015). Exploratory Study on LearnerDriven Blended Learning Environment (online). Proceeding Journal of Education, Psychology and Social Science Research. www.e-jounaldirect.com.

Brook, J. Dan Upitis, R. (2015). Can an online tool support contemporary independent music teaching and learning?. Music Education Reseach, 17(1), 34-47.

Chen, C. C., \& Jones, K. T. (2007). Blended Learning vs. Traditional Classroom Settings: Assessing Effectiveness and Student Perceptions in an MBA Accounting Course. The Journal of Educators Online, 48(1), 1-15.

Cho, M. H., \& Tobias, S. (2016). Should Instructors Require Discussion in Online Course? Effect of Online Discussion on Community of Inquiry, Learner Time, Satisfaction and Achievement. International Review of Research in Open and Distributed Learning, 17(2), 124-142.

Ermilyaz, M. (2015). The Effectiveness of Blended Learning Environments. Contemporary Issues in Education Research - 4th Quarter Journal, 8(4), 251-256.

Farlane, D. A. (2011). A Comparison of Organizational Structure and Pedagogical Approach: Online versus Face-to-face. The Journal of Educators Online, 8(1), 1-43.

Geng, G. (2011). Investigation of Teachers' Verbal and Non-verbal Strategies for Managing Attention Deficit Hyperactivity Disorder (ADHD) Students' Behaviours within a Classroom Environment. Australian Journal of Teacher Education, 36(7), 17-30.

Geraci, L., \& Cabe, D. P. (2006). Examining the basis for illusory recollection: The role of remember/know instructions. Psyconomic Bulletin\& Review, 13(3), 466-473.

Hsu, P. S., Dyke, M. V, \& Chen, Y. (2015). Examining the Effect of Teacher Guidance on Collaborative Argumentation in Middle Level Classrooms. Research in Middle Level Education, 38(9), 1-11.

Jaleel, S., \& Vergins, M. A. (2015). Knowledge Creation in Constructivist Learning. Universal Journal of Educational Research, 3(1), 8-12. 
Roqobih \& Ambarwati, Implementation of Blended Learning...

Kilic, D. (2016). Pre-service Teachers' Conceptual Structures and Reasoning Patterns on Animal Classification. Universal Journal of Educational Research, 4(4), 830-841.

Litasari, K. N., Setiati, N., \& Herlina, L. (2014). Profil Pembelajaran Biologi Berbasis Laboratorium dan Implikasinya terhadap Hasil Belajar Siswa di SMA Negeri SeKabupaten Semarang. Unnes Journal of Biology Education, 3(2), 172-179.

Okaz, A. A. (2015). Integrating Blended learning in Higher Education. Procedia Social and Behavioral Sciences, 186, 600-603.

Putri, M. A., Jampel, N., \& Suartama, K. I. (2014). Pengembangan E-Learning Berbasis Schoology pada Mata Pelajaran IPA Kelas VIII di SMP Negeri 1 Seririt. Journal Edutech Universitas Pendidikan Ganesha Jurusan Teknologi Pendidikan Ganesha Jurusan Teknologi Pendidikan, 2(1), 1-11.

Sicat, A. S. (2015). Enhancing College Student's Proficiency in Business Writing Via Schoology. International Journal of Education and Research, 3(1), 160-178.

Suana, W., Maharta, N., Nyeneng, I. D. P. (2017). Design and Implementation of SchoologyBased Blended Learning Media for Basic Physics I Course. Jurnal Pendidikan IPA Indonesia, 6(1), 170-178.

Tara, S. N., \& Bindu, R. L. (2015). Effect of blended learning strategy on achievement in Biology and social and environmental attitude of Students at secondary level. $i$ manager's Journal on School Educational Technology, 11(4), 39-52.

Wai, C. C., \& Seng, E. L. K. (2015). Measuring the effectiveness of blended learning environment: A case study in Malaysia. Education and Information Technologies, 20(3), 424-443.

Xu, Y. D., Meyer, K. A., \& Morgan, D. (2008). Piloting a Blended Approach to Teaching Statistics in a College of Education: Lessons Learned. The Journal of Educators Online, 5(2), 1-20.

Yapici, I. U., \& Akbayin, H. (2012). High School Students's Views on Blended Learning. Turkish Online Journal of Distance Education, 13(4), 125-139. 